\title{
Cardiac Conduction System Disorders
}

Editors

ERIC N. PRYSTOWSKY

BENZY J. PADANILAM

\section{CARDIAC \\ ELECTROPHYSIOLOGY CLINICS}

www.cardiacEP.theclinics.com

Consulting Editors

RANJAN K. THAKUR

ANDREA NATALE

December 2021 • Volume 13 • Number 4 